Acta Universitatis Nicolai Copernici • Pedagogika XL/2/2020

Nauki Humanistyczno-Społeczne • Zeszyt 452

DOI: http://dx.doi.org/10.12775/AUNC_PED.2020.014

\author{
Artur Jabłoński \\ Prywatna Szkoła Podstawowa \\ Naja Szkòła w Wejherowie \\ https://orcid.org/0000-0002-3803-1035
}

\title{
PoWieść Jana Rompskiego Wurvanô spJÉva JAKO METAFORA PROJEKTU NARODOWEGO ZRZESZYŃCóW
}

\author{
Jan Rompski's Novel Wurvanô Spjéva as a Metaphor \\ for the National Project of the Zrzeszyńcy Group
}

\begin{abstract}
Abstrakt
W 1943 roku kaszubski pisarz Jan Rompski napisał powieść zatytułowaną Wurvanô spjéva, którą można odczytać jako metaforę projektu narodowego skierowanego do Kaszubów, stworzonego przez inteligencki krąg przyjaciół w realiach II Rzeczypospolitej lat 30. XX wieku. Jan Rompski był współzałożycielem i ideologiem grupy ideowo-literackiej Zrzeszyńców, która kontynuowała tradycje ruchu kaszubskiego, swoimi korzeniami sięgającego pierwszej połowy XIX stulecia. Niniejszy artykuł jest próbą odpowiedzi na pytanie, co stanowiło filary projektu Zrzeszyńców, a także jakie były jego podstawowe założenia, mające pomóc w kreacji wyobrażenia narodu, którego przedstawicielami się czuli. Należało się również przyjrzeć, jak Jan Rompski przeniósł owe założenia na karty powieści Wurvanô spjéva. Analizując powieść i teksty publicystyczne Zrzeszyńców, posłużyłem się metodą krytycznej analizy dyskursu. Jeśli naród to zbiór elementów połączony jakimiś więzami, to tym, co spaja Kaszubów, są: język, kultura i polityka.
\end{abstract}


Słow a kluczowe: Kaszubi, projekt narodowy, Zrzeszyńcy, literatura

\begin{abstract}
In 1943, the Kashubian writer Jan Rompski wrote a novel entitled Wurvanô spjéva, which can be read as a metaphor for a national project aimed at Kashubians, created by an intellectual circle of friends in the realities of the Second Polish Republic in the 1930s. Jan Rompski was a co-founder and ideologist of the Zrzeszyńcy ideological and literary group, which continued the traditions of the Kashubian movement with its roots dating back to the first half of the $19^{\text {th }}$ century. This article is an attempt to answer the question of what were the pillars of the Zrzeszyńcy project, as well as what were its basic assumptions that were to help create the image of the nation they felt they represented. It was also necessary to look at how Jan Rompski transferred these assumptions to the pages of the novel Wurvanô spjéva. While analyzing the novel and journalistic texts of Zrzeszyńcy, I used the method of critical discourse analysis. If the nation is a set of elements connected by some bonds, then what binds the Kashubians together are: language, culture and politics.
\end{abstract}

Ke y w o rd s: Kashubians, national project, Zrzeszyńcy, literature

\title{
Wprowadzenie
}

T Taszubska grupa ideowo-literacka Zrzeszyńców ${ }^{1}$ nie jest szerzej zna- na polskiemu czytelnikowi - poza badaczami ruchów mniejszości narodowych i etnicznych oraz literatur mniejszościowych. Podobnie postać Jana Rompskiego, pisarza urodzonego w 1913 roku w Kartu-

${ }^{1}$ Zrzeszyńcy to grupa ideowo-literacka, którą tworzyli nauczyciele i pisarze kaszubscy, działacze Zrzeszenia Regionalnego Kaszubów powstałego w 1929 r. w Kartuzach, redaktorzy gazety „Zrzesz Kaszëbskô” wychodzącej w latach 1933-1939 i 1945-1947. Należeli do niej m.in. Stefan Bieszk, ks. Franciszek Grucza, Aleksander Labuda, Jan Rompski, Ignacy Szutenberg i Jan Trepczyk. Będę używał nazwy Zrzeszyńcy, ponieważ jest ona najbliższa kaszubskiemu słowu „Zrzeszińcë”, jakim określały się osoby tworzące tę ideowo-literacką grupę. W polskojęzycznej literaturze przedmiotu można znaleźć również formę Zrzeszeńcy, a także Zrzeszowcy. 
zach i zmarłego w 1969 roku w Toruniu. Ten współredaktor gazety „Zrzesz Kaszëbskô", kaszubski poeta, autor licznych dramatów i tylko jednej powieści, etnograf i działacz społeczny, w drugiej połowie lat 30. $\mathrm{XX}$ wieku dojrzał do roli ideologa Zrzeszyńców. W tym samym czasie ostatecznego kształtu nabrał projekt narodowy skierowany do Kaszubów. Tekst ten będzie próbą odpowiedzi na pytanie, co stanowiło filary projektu Zrzeszyńców, a także jakie były jego podstawowe założenia, mające pomóc w kreacji wyobrażenia narodu, którego przedstawicielami się czuli. Należało się również przyjrzeć, jak Jan Rompski przeniósł te założenia do tekstu powieści zatytułowanej Wurvanô spjéva (Urwana pieśń), powstałej w zasadniczej części w 1943 roku.

Zanim podejmę główny temat, przedstawię krótko założenia teoretyczne mojej analizy. Będę się posługiwał w tym tekście krytyczną analizą dyskursu. Za Michaiłem Bachtinen przyjąłem, że słowo funkcjonuje w kontekście historyczno-społecznym, a użycie słowa przez konkretne społeczeństwo wpływa na jego znaczenie, które determinuje istnienie znaków stanowiących podstawę istnienia ideologii. Ideologia właśnie jest centralnym pojęciem w Bachtinowskim rozumieniu języka: „Wszystko, co jest ideologiczne, posiada znaczenie, a ponieważ wyobraża, przedstawia lub zastępuje coś, co znajduje się poza nim jest znakiem"2. Ideologia to system znaków, który ci, którzy posiedli wiedzę, wykorzystują - reprodukują i utrwalają w relacji ze społeczeństwem - dla władzy. Interpretację zjawisk społecznych i kulturowych przynosi nauka, którą władza wykorzystuje do ideologizacji / homogenizacji społeczeństwa, czyniąc to za pośrednictwem intelektualistów. Taką ocenę sformułował Antonio Gramsci. Jak pisze Adela Kożyczkowska, która szczegółowo analizuje jego rozumowanie: „Złudne jest myślenie, że językowa wiedza społeczno-humanistyczna nie przesądza o człowieczym funkcjonowaniu, w rzeczywistości bowiem wiedza ta przejmuje całkowicie władzę nad tożsamością swych podmiotów"3. Badaczka dodaje, że „myślenie formacji społecznych, które wytwarzane

2 M. Bachtin, Nauka o ideach a filozofia języka, w: Bachtin - dialog, język, literatura, red. Eugeniusz Czaplejewicz, Edward Kasperski, Warszawa 1983, s. 75.

3 A. Kożyczkowska, Kaszubszczyzna. Pedagogicznie o języku i tożsamości, Gdańsk 2019, s. 34. 
są przez każdą kulturę, jest rozpoznawane w języku (mówionym i pisanym)"'s.

Omówmy jeszcze metodologiczne założenia sformułowane przez Teuna van Dijka, przedstawiciela krytycznej analizy dyskursu, który badając struktury językowe, poszerza je i stwierdza, że „należy patrzeć ponad dyskursem, biorąc pod uwagę jego środowiska: kognitywne, społeczne, polityczne, kulturowe i historyczne"5. Artur Stęplewski, komentując tezy van Dijka, zauważa, że: „[r]eferencjalność języka jest zatem uwarunkowana socjokulturowo", i dodaje, że jeśli wziąć pod uwagę homogenizację społeczeństwa poprzez planowe kontrolowanie dostarczanej wiedzy oraz sterowanie jej interpretacją i zachowaniami społecznymi, to: „[p]raktyczne z tego punktu widzenia jest skonstruowanie narodu na podstawie wspólnych wartości, które określają granice tego, co oznacza MY"6. Podążając za sformułowaniami Adeli Kożyczkowskiej, będącymi podsumowaniem analizy Michela Foucaulta, należy pamiętać, że poszczególne systemy wiedzy, już jako zjawiska społeczne, wytwarzają skutki zarówno pozytywne, jak i negatywne. Do tych pierwszych należy zaliczyć wytwarzanie lub reprodukowanie względnie trwałej struktury społecznej. Te drugie to tłumienie, zapobieganie, wykluczanie, eliminowanie pewnych elementów ze struktury społecznej i tym samym z produkowanej kultury

4 Tamże, s. 34.

5 T. van Dijk, Kontekstualizacja $w$ dyskursie parlamentarnym, w: Krytyczna analiza dyskursu, red. A. Duszak, N. Fairclough, Kraków 2008, s. 216.

6 A. Stęplewski, „Czy Atatürk był gejem?”. Konstruowanie Obcego w tureckich i greckich mediach, „Dziennikarstwo i Media”, 2020 nr 14, s. 48; tenże, Semioza pisma. Cyrylica i łacinka w serbskim i chorwackim dyskursie narodowym na tle słowiańskim, Poznań 2018, s. 29.

7 A. Kożyczkowska, Kaszubszczyzna. Pedagogicznie o języku i tożsamości, dz. cyt., s. 32. Por. M. Foucault, Nadzorować i karać. Narodziny więzienia, Warszawa 1993, s. 30-31. 


\section{Tło historyczne i społeczne powstania projektu narodowego Zrzeszyńców}

Przyjęte założenia wymuszają przedstawienie historycznego i społecznego tła stworzenia projektu narodowego Zrzeszyńców. Jego założenia ideologiczne krystalizowały się między rokiem 1929 a 1933, to jest w okresie od założenia Zrzeszenia Regionalnego Kaszubów w Kartuzach do wydania pierwszych numerów gazety „Zrzesz Kaszëbskô” w Gdyni. Były to lata światowego kryzysu gospodarczego, który uderzył w rolnictwo i przemysł, co na obszarze Kaszub najbardziej odczuwalne było dla robotników i firm kooperujących z portem w Gdyni. Kryzys poprzedziła prawie dekada, która nie należała do łatwych okresów w historii Kaszubów. Od roku 1920, tj. od momentu, gdy polska administracja - w ramach uregulowań pokoju paryskiego zawartego w 1919 roku - przejęła od Niemiec część ziem kaszubskich, rozpoczęły się procesy mające scalić Pomorze z pozostałymi dzielnicami II Rzeczypospolitej. Armia polska zachowywała się niczym okupant. Powołana do zbadania takiego postępowania sejmowa Komisja Pomorska w raporcie donosiła:

Powiaty pucki i wejherowski robią nad wyraz smutne, wprost przygniatające wrażenie. Nie odczuwa się tutaj powiewu ducha polskiego, raczej wszystko tchnie złowrogą nienawiścią ku polskim władzom, a głębokie rozczarowanie rozsiadło się szeroko w duszach rybaków kaszubskich. [...] Wojsko, jak wszędzie na Pomorzu, zrobiło i tu polskości najgorszą przysługę szorstkim traktowaniem ludności, dla której ducha nie miało żadnego zrozumienia, i najrozmaitszymi szykanami i nieprawnymi rekwizycjami, kwaterunkami itd. [...] To wojsko, witane z nieopisanym uwielbieniem jako oswobodziciele z jarzma pruskiego, zaczęło tę skromną, cichą, pracowitą ludność traktować jak naród podbity, zachowywało się jak w okupowanym kraju 8 .

Obsadzanie stanowisk w administracji ówczesnego województwa pomorskiego urzędnikami polskimi, sprowadzonymi z innych części

8 Sejm Rzeczypospolitej o Pomorzu w 1920 roku. Sprawozdanie Komisji Pomorskiej, oprac. J. Borzyszkowski, P. Hauser, Gdańsk 1985, s. 44, 45, 50. 
Rzeczypospolitej, było normą. Rodzima inteligencja najczęściej podnosiła w swoich skargach do rządu, że ludność pomorska jest dyskryminowana przez napływających migrantów z Polski, że Kaszubów sprowadza się do rangi obywateli drugiej kategorii, że trwa ich wynarodawianie nazywane repolonizacją Pomorzan, że są szykanowani przy podziale ziemi $\mathrm{w}$ okresie reformy rolnej, a także $\mathrm{w}$ dostępie do miejsc pracy w budującej się Gdyni. Innym jeszcze przejawem szykan i dyskryminacji był przymus pracy nauczycieli Kaszubów na ziemiach niekaszubskich, co równało się wymuszonej emigracji poza pomorską ojczyznę 9 .

Administracja polska dbała przede wszystkim o jak najszybsze scalenie Pomorza z pozostałymi ziemiami przyznanymi Polsce po zakończeniu I wojny światowej ${ }^{10}$, a zatem zależało jej na asymilacji, a nie na zachowaniu odrębności. Władze, przede wszystkim policyjne i wojskowe, oskarżyły Kaszubów o separatyzm. W tajnych raportach składanych wojewodzie pomorskiemu oraz starostom powiatowym nieufnie i negatywnie odnoszono się do pomorskich autochtonów. Działania przedstawicieli polskiego rządu w terenie wzmacniały w Kaszubach poczucie bycia gorszymi obywatelami ${ }^{11}$. Aleksander Majkowski, niekwestionowany lider powstałego w 1908 roku ruchu Młodokaszubów ${ }^{12}$, w liście do Antonina Frinty, swojego czeskiego przyjaciela z Uniwersytetu Karola w Pradze, w 1931 r. pisał: „[...] czynniki rządowe w województwie w Toruniu zajmują - nie otwarcie, ale tym skuteczniej poufnie - stanowisko wprost wrogie wobec życia szczepowego Kaszubów [... ${ }^{13 "}$. I dalej, w tym samym liście, konstatował:

9 J. Kutta, Druga Rzeczpospolita i Kaszubi, Bydgoszcz 2003.

10 Tamże, s. 13.

11 Tamże, s. 177.

12 Młodokaszubi to nazwa ruchu inteligencji kaszubskiej, który zapoczątkowany został w 1908 r. m.in. przez Aleksandra Majkowskiego i Jana Karnowskiego poprzez wydawanie gazety „Gryf”. W 1912 r. w Sopocie doszło do zawiązania Towarzystwa Młodokaszubów. Za cel Młodokaszubi stawiali sobie obudzenie w Kaszubach własnej świadomości etnicznej oraz promowanie wiedzy o nich, a także włączenie ich w polityczny nurt życia ogólnopolskiego.

13 D. Szymikowski, Z dziejów stosunków kaszubsko-czeskich. Korespondencja Aleksandra Majkowskiego z Antoninem Frinta 1912-1935, Gdynia 2006, s. 23. 
Ja, który całą duszą parłem do ścisłego zespolenia Kaszubów z Polską, gdyż z dziejów Słowian nadbałtyckich wiem, że na rozdrabnianiu się poszczególnych szczepów słowiańskich oparł Niemiec swoją skuteczną politykę tępicielską wobec nas, w warunkach obecnych stoję niemal bezradny wobec tego, co się dzieje, i z wielką troską patrzę w przyszłość14.

W ideologii Zrzeszyńców elementy konstruujące naród to język, kultura i polityka ${ }^{15}$. Tymczasem władza II Rzeczypospolitej nie uznawała języka kaszubskiego i negatywnie odpowiadała na postulaty nauczania go w szkołach. W sukurs władzy przychodzili uczeni. Profesor Uniwersytetu Poznańskiego Mikołaj Rudnicki przestrzegał przed autonomią językową Kaszubów, widząc w tym „dogodną dla Niemiec dywersję”. Kultura sprowadzana była najczęściej do ludowości i najlepiej, jeśli wyrażała się w wymyślonym stroju „ludowym”, tańcach i patriotycznym śpiewie podczas państwowych dożynek, a za uprawianie polityki groził areszt i cenzura prewencyjna.

Projekt Zrzeszyńców był zatem odpowiedzią na dyskryminację ze strony czynników rządowych. Zakładał zinstytucjonalizowanie działalności, czego zalążkiem było Zrzeszenie Regionalne Kaszubów. Jako oręż, a jednocześnie medium, za pomocą którego ważne treści miały trafiać do każdego, miała służyć Zrzeszyńcom gazeta, a także wydawana przez nich literatura. Początkowo, po rozmowach Aleksandra Majkowskiego i Aleksandra Labudy (prezesa i wiceprezesa ZRK) z Władysławem Pniewskim, nauczycielem i publicystą z Gdańska, zdecydowano wspólnie o założeniu spółdzielni wydawniczej, która będzie wydawała kwartalnik „Gryf” (czwartą, redagowaną przez Pniewskiego, edycję pisma założonego w 1908 roku przez Majkowskiego) i miesięcznik „Gryf Kaszubski”, którego redaktorem został Labuda. W 1932 roku współpraca została przerwana. Aleksander Labuda, Jan Trepczyk, Jan Rompski i Ignacy Szutenberg zdecydowali wówczas o założeniu gazety „Zrzesz Kaszëbskô”, której pierwszy, okazowy numer wydali w kwietniu

14 Tamże, s. 25.

15 Por. A. Kożyczkowska, Kaszubszczyzna. Pedagogicznie o języku i tożsamości, dz. cyt., s. 87. 
1933 roku $^{16}$. Fakt powstania organizacji i wydawania własnej gazety był oznaką uzyskania przez Kaszubów praw obywatelskich ${ }^{17}$, ale też stał się przyczyną politycznego wykluczenia Zrzeszyńców.

Narodowy projekt Zrzeszyńców zakładał upodmiotowienie się Kaszubów w walce o tożsamość $\mathrm{w}$ świetle konfliktu między ideologią narodową i państwową. Nie mogły też istnieć, według władzy, która chciała wyznaczać granice etniczności Kaszubów, równorzędne narody $\mathrm{w}$ jednym państwie ${ }^{18}$. Wydaje się, że Zrzeszyńcy rozumieli, co było sumą ich doświadczeń, że nie mogą wciąż tłumaczyć sensu swojej walki, lecz że ich dyskurs - podeprę się tutaj po raz kolejny myśleniem Michela Foucaulta zaczerpniętym z jego szerokich badań - poprzez to „dlaczego i poprzez co" walczą, ,jest władzą", którą chcieli zdobyć19. Dążyli do pozyskania dla swojej walki szeroko rozumianej inteligencji pomorskiej, która skupiona była w Toruniu, stolicy ówczesnego województwa pomorskiego. Dlatego właśnie w tym mieście planowali zorganizować Zjazd / Kongres Inteligencji Kaszubskiej. Te plany przerwał jednak wybuch II wojny światowej.

\section{Powieść Wurvanô spjéva jako metafora projektu}

Powieść Jana Rompskiego Wurvanô spjéva ${ }^{20}$ wydaje się soczewką tożsamościowych dążeń Zrzeszyńców. Autor licznych dramatów, liryków i powieści Wurvanô spjéva należy do czołowych literatów kaszubskich. $\mathrm{W}$ jego utworach nie brakuje technik znanych z literatury romantycznej, czy wręcz fantastycznej, nieprawdopodobnych zdarzeń i postaci ze

16 D. Szymikowski, Zrzesz Kaszëbskô w latach 1933-1939, Bolszewo 2010, s. $21-31$.

17 A. Kożyczkowska, Kaszubszczyzna. Pedagogicznie o jezyku i tożsamości, dz. cyt., s. 79.

18 Por. tamże.

19 M. Foucault, Porządek dyskursu. Wykład inauguracyjny wygłoszony w College de France 2 grudnia 1970, Gdańsk 2002, s. 8.

${ }^{20}$ Od powstania powieści do ukazania się tego artykułu minęło 77 lat. $W u$ rvanô spjéva dostępna jest w rękopisie w zbiorach Muzeum Piśmiennictwa i Muzyki Kaszubsko-Pomorskiej w Wejherowie. Placówka ta zapowiedziała wydanie powieści w 2021 r. 
świata marzeń sennych czy mitologii, zarówno europejskich, jak i pomorskiej (kaszubskiej). Jednak często łączy on ową fantastykę z doświadczeniem literatury realistycznej. Czyni tak również w powieści Wurvanô spjéva, która może być odczytana jako metafora projektu narodowego Zrzeszyńców. Opisując procesy tożsamościowe - związane z nimi trudności i konflikty - zachodzące na Kaszubach w II Rzeczypospolitej w okresie międzywojennym, a przede wszystkim w przededniu II wojny światowej, Jan Rompski stworzył realistyczno-fantastyczną narrację o narodzie kaszubskim. Nie bez znaczenia jest także fakt, że uczynił to w niezwykle trudnym czasie. Wurvanô spjéva została bowiem napisana w 1943 roku, między pierwszym aresztowaniem Jana Rompskiego jako żołnierza Tajnej Organizacji Wojskowej „Gryf Pomorski” w lutym tego roku a jego ponownym zatrzymaniem i osadzeniem w KL Stutthof w lutym 1944 roku.

Akcja powieści Wurvanô spjéva rozpoczyna się w letnich miesiącach 1939 roku, a więc tuż przed wybuchem II wojny światowej, i kończy w październiku tego samego roku, gdy hitlerowska III Rzesza rozpoczęła na dobre swoje rządy na kaszubskim Pomorzu. Nie brakuje też odniesień do wcześniejszego czasu - np. budowy portu i miasta w Gdyni - ale są to raczej epizody mające stanowić tło wydarzeń 1939 roku i dylematów kaszubskiego inteligenta. Bohaterem powieści Jana Rompskiego jest bowiem młody inteligent właśnie: malarz i urzędnik mieszkający w Wejherowie. Na marginesie tylko wspomnę, że człowiek ten zakochany jest w dziewczynie z Kartuz, ale ich przecinające się drogi połączą się dopiero w epilogu powieści, gdyż życie złączy wcześniej bohatera z inną kobietą, uratowaną z odmętów jeziora podczas letniej burzy, a jego wcześniejsza wybranka wyjdzie za mąż za kogoś zupełnie innego.

Należy wyjaśnić jeszcze w tym miejscu ważną dla zrozumienia powieści kwestię imion dwóch postaci: głównego bohatera Mirchova i jego przyjaciela, aktywisty kaszubskiego Chmiela. Otóż obaj mają swoje alter ego - Rãbiôka i Łabãdzczégò - dla których Mirchów i Chmiél są archetypami, dla nich zaś pierwowzorem są postacie autentyczne: Jan Rompski i Aleksander Labuda. Szczególnie w przypadku Rãbiôka można zakładać, że bohater ten przechodzi pewną metamorfozę, by stać się Mirchòvã. Przy czym należy pamiętać, że „mjirchóv” w języku Zrze- 
szyńców oznacza „bohatera”. W młodym inteligencie kaszubskim żyje więc o wiele starszy, dziejowy „bohater”.

Wurvanô spjéva jest wieloznaczna zarówno w swojej wymowie ogólnej, jak i w poszczególnych wątkach - niektórych tylko zasygnalizowanych, a innych bardzo rozbudowanych ${ }^{21}$. Na potrzeby tego artykułu skupię się na czterech sprawach, które zajmują ważne miejsce w powieści i są istotne dla strategii tożsamościowej Zrzeszyńców: poczuciu narodowej odrębności, języku, kulturze i polityce.

\section{Naród w projekcie Rompskiego}

Jan Rompski w swojej powieści dzieli Kaszubów na aktywnych i biernych. Ci drudzy żyją bezrefleksyjnie, nie analizując swojej kaszubskości (w rozumieniu świadomej przynależności do wspólnoty narodowej) i nie angażując się w jakikolwiek sposób w odrodzenie narodowe. Wśród tych aktywnych pisarz wyróżnia z kolei dwie postawy. Pierwszą reprezentują ci, którzy przeszli „regionalną szkołę”22 (Wurvanô spjéva, MPiMKP - SJR, sygn. 3, s. 83) ${ }^{23}$ i uznają kaszubszczyznę za gwarę, a lud za „wykoślawionych Polaków” (Wurvanô spjéva, sygn. 3, s. 83). Jest ich więcej niż takich jak on sam, przyjmujących na siebie rolę liderów narodowego odrodzenia. $\mathrm{Ci}$, czujący odpowiedzialność za odrodzenie Kaszubów, własną kulturę traktują jak „ukochaną matkę” (Wurvanô spjéva, sygn. 3, s. 83) i są przekonani o językowym statusie kaszubszczyzny oraz deklarują otwarcie swoją narodowość kaszubską.

Najbardziej boli jednak powieściowego bohatera Mirchova/ Rąbskjégò, gdy „szowjinjiscë polskji” [polscy szowiniści] (Wurvanô

21 Szczegółowe omówienie powieści i jej znaczeń można znaleźć w pracy doktorskiej: A. Jabłoński, Narracja Jana Rompskiego o narodzie kaszubskim, rozprawa doktorska napisana pod kierunkiem prof. Jolanty Tambor, Katowice 2019, Internet: https://fbc.pionier.net.pl/details/nnV4nwq (dostęp: 16.04.2020).

22 Wszystkie tłumaczenia z języka kaszubskiego na język polski pochodzą od autora artykułu.

23 Rękopis powieści znajduje się w dziale rękopisów wejherowskiego muzeum i oznaczony jest skrótem MPiMKP - SJR, sygn. 3: Muzeum Piśmiennictwa i Muzyki Kaszubsko-Pomorskiej - Spuścizna Jana Rompskiego, sygnatura 3. 
spjéva, sygn. 3, s. 84) publicznie drwią z poczucia narodowego Kaszubów. Żyjąc i działając w świecie, w którym zasadą legitymizacji narodu było państwo i nacjonalizm, Zrzeszyńcy chcieli, by Kaszubi mogli w pełni korzystać z przywilejów bycia równymi w państwie prawa. Jednocześnie domagali się praw szczególnych, aby zachować i rozwinąć własną przestrzeń w państwie i społeczeństwie większościowym, by nie dać się zdominować i pozostać współgospodarzami na własnej ziemi.

W ideologii Zrzeszyńców Kaszubi stanowili „rdzeń pacierzowy” - jak sami to określali - całego Pomorza i byli ostatnimi potomkami oraz spadkobiercami „potężnego niegdyś narodu Weletów”, który zamieszkiwał tereny na północ od Noteci i Warty i na zachód od dolnej Wisły, sięgające aż po Łabę ${ }^{24}$. Według autora artykułu Kaszubi, poznajmy swą przeszłość! istotą przedstawienia dziejów Kaszubów-Pomorzan powinno być wskazanie na dobrowolne „łączenie się Pomorzan z Polakami, co tym większą ma wartość na przyszłość dla obu narodów, im więcej one są świadome swych odrębności narodowych" 25 . Warto tu zacytować Miroslava Hrocha, który jako znawca historii ruchów narodowych (szczególnie w Europie Środkowo-Wschodniej) podobne zjawiska komentuje w sposób następujący: „Im bardziej sławna była narodowo aktualizowana przeszłość, im silniejsze było kiedyś państwo, do którego mógł się ruch narodowy odwołać, tym większy nacisk kładziono na historię jako na jeden z podstawowych argumentów za prawem do narodowego istnienia" ${ }^{26}$.

Jan Rompski nie raz przywołuje w powieści ten „welecki” mit narodowy. Gdy pociąg mija Bydgoszcz, jego bohater jedzie już teraz „w Krôj Weletów" [w Kraj Weletów]. Kiedy indziej powieściowy narrator grzmi o inteligentach kaszubskich, że zapomnieli, iż są „òtrokama Weletów” [potomkami Weletów]. W scenie rozmowy z Zofią, koleżanką z pracy w urzędzie miasta Wejherowa, Rãbiôk marzy i skarży się jednocześnie:

24 [b.a.], Kilka stów o nazwach i herbie Kaszubów, „Zrzesz Kaszëbskô”, 1933 rok 1 nr 31, s. 1.

25 [b.a.], Kaszubi, poznajmy swą przeszłość!, „Zrzesz Kaszëbskô”, 1933 rok 1 nr 24, s. 2 .

${ }^{26}$ M. Hroch, Małe narody Europy, Wrocław 2003, s. 131. 
- Czej téż sã dożdómë czasów, że na karajkach mdą remùsovi òtrocë wiozlë kaszëbsczé ksążczi w chëcze gbùrów i gbùrczãt, w prodżi miast, a mdą jich rozmielë wszëtcë? Nie mdą mielë za letczich w głowie Grifitów z gniôzda Weletów. Bò wiédz, Zófiô, że më Kaszëbi to le nédżi wiôldżégò czedës nôroda Weletów. Jak wispa jesmë, òblóny wòdama, chtërne wëpłókiwają piôsczi i corôz barżi sã wżérają w ląd. Nôród òkrãtników i ricerzów dôwno pòwiesył swòjã gùslã, ò chtërny strënë le tej-sej wiaterk côrnie, dobiwając bòlesną skargã...27.

[Czy jeszcze doczekamy czasów, że na taczuszkach ${ }^{28}$ będą remusowi potomkowie wieźli kaszubskie książki do domów bogatych właścicieli i rolników, w progi miast, i wszyscy ich rozumieć będą? Nie będą ich traktowali jak pomylonych Gryfitów z gniazda Weletów. Bo wiedz, Zofio, że my Kaszubi to tylko resztki wielkiego niegdyś narodu Weletów. Jesteśmy jak wyspa oblana wodami, które wypłukują piasek i coraz bardziej wżerają się w ląd. Naród okrętników i rycerzy dawno już zawiesił swoje gęśle, a których struny tylko czasami jeszcze wiatr zadzieje, dobywając bolesną skargę...]

Zadanie, jakie stawiali przed sobą Zrzeszyńcy, nie było łatwe w rzeczywistości II Rzeczypospolitej. Panujące w polskiej myśli politycznej w dwudziestoleciu międzywojennym tendencje najkrócej i chyba najdobitniej opisał historyk Tadeusz Łepkowski:

Przypomnijmy to, co w 1937 r. pisała „Myśl Narodowa” [czasopismo - A.J.], jak mianowicie definiowała naród i rasę. Otóż czytamy: „naród jest to społeczeństwo, którego trzon stanowią ludzie jednej rasy związani moralnie poczuciem wspólności i pierwszeństwem wzajemnych obowiązków wobec siebie, poczuciem więźby organicznej z przeszłymi swymi pokoleniami i troską o pokolenia przyszłe". Ale skoro niezbyt precyzyjnie zdefiniowany „trzon" narodu ma być jednorasowy, to wypada wyjaśnić, co stanowi rasę? Jest to „zespół ludzi, którzy odziedziczyli pewne wspólne cechy fizyczne i cechy duchowe, urobione długowieczną kulturą".

27 J. Rompski, Wurvanô spjéva, w: Spuścizna Jana Rompskiego, sygn. 3, k. 79-80.

${ }^{28}$ To nawiązanie do powieści Aleksandra Majkowskiego Z̈ëcé ë przigòdë Remùsa, w której tytułowy Remus kroczy przez Kaszuby ze swoim wędrownym kramem - taczką pełną książek. 
O ile autorytarny i pararasistowski był narodowy model polskości w myśli endeckiej i ugrupowań z niej się wywodzących, o tyle piłsudczycy u władzy lansowali raczej etatystyczny model narodu. Polskość miała być upaństwowiona, co w znacznej mierze (może poza krótkim epizodem Ozonu) zakładało multietniczność narodu. Polskość narodowa to zetatyzowana wspólnota mieszkańców Polski, przede wszystkim jednak osób narodowości polskiej oraz spolonizowanych elit mniejszości narodowych ${ }^{29}$.

W takich warunkach idea odrodzenia Kaszubów - narodu bez państwa, który nie dąży do jego utworzenia - do którego sanacji doprowadzi rodzima inteligencja, była myśleniem wybiegającym znacznie poza lata 30. XX wieku.

\section{Język w projekcie Rompskiego}

Powieściowy bohater, prezentując publicznie swoje poglądy na temat języka kaszubskiego jako autonomicznego języka słowiańskiego, jest niezrozumiany. Ci sami „szowjinjiscë polskji” [polscy szowiniści] (Wurvanô spjéva, sygn. 3, s. 84), którzy nie rozumieją dążeń narodowych Kaszubów, drwią także z pojęcia języka kaszubskiego. To echo polemik, jakie w rzeczywistości toczyli redaktorzy „Zrzeszë Kaszëbskji” z przedstawicielami inteligencji polskiej, odmawiającymi Kaszubom prawa do odrębności językowo-etnicznej. Tymczasem przeświadczenie bohatera powieści o konieczności ochrony i rozwoju języka jako jednego z podstawowych elementów budujących tożsamość narodową jest tak ugruntowane, że gdy redaktor jednej z pomorskich (gdyńskich) gazet nakłania go do pisania skaszubioną polszczyzną, jest on gotowy zrezygnować ze współpracy. Stawia sprawę jednoznacznie:

- Chcoł jem z Vastą pogodac $\mathrm{v}$ spravje nich feljetonov. [...]

- Chce Vasta, żebem zmjenjeł pjisovnję do vigode redakcji i pjisoł skaszebjoną polszczezną. [...] Nje, vasto redaktorze. Ten bót be mje wobcesnął pjętę. Nji móg bem sę pokazac Kaszebom na wulice, a nje lubję v checze sedzec, kjej słuńce chłosci. Meszlę, że jem dobrze rozmjani?

29 T. Łepkowski, Historyczne kryteria polskości, „ZNAK”, 1987 nr 11-12(390-391), s. 9-10. 
- Rozmjejã. Vjic nje chce vasta nick òdstąpic.

- Nji mogę.

- Szkoda. Tej muszime naszę vespolną procę przervac.

- Jak Vasta wuvożo. Mjij na tim tracę, jak bem zarobjił godząc sę na propozicję mje daną.

- Proszę sę jesz nameslec, chcoł bem rod mjec cos kaszebskjigo, bo to je aktualni.

- Ach, temu! Dlo tego celca aktualnoscą zvanigo mom koszlavjic movę i pjisovnję, chterną pjiszą v vjikszim dzelu pozitivisce kaszebskji? Anji mje sę snjije i to je moje wostatni słovo wo tim ${ }^{30}$.

[- Chciałem z panem porozmawiać w sprawie tych felietonów. [...]

- Chce pan, żebym zmienił pisownię dla wygody redakcji i pisał skaszubioną polszczyzną. [...] Nie, panie redaktorze, ten but oszorowałby mi piętę. Nie mógłbym się pokazać Kaszubom na ulicy, a nie lubię siedzieć w domu, kiedy słońce zaprasza. Myślę, że pan mnie rozumie?

- Rozumiem. Zatem nie ustąpi pan.

- Nie mogę.

- Szkoda, bo musimy naszą współpracę przerwać.

- Jak pan uważa. Mniej na tym stracę, niżbym się zgodził na otrzymaną propozycję.

- Proszę to jeszcze przemyśleć, chętnie chciałbym mieć coś kaszubskiego, bo to jest aktualne.

- Więc to dlatego? Dla cielca aktualnością zwanego mam koślawić mój język i pisownię, którą pisze większość pozytywistów kaszubskich? Ani mi się śni i to jest moje ostatnie słowo w tym temacie.]

Rompski nie mógł pozostawić swojemu powieściowemu alter ego innego wyboru. Miał świadomość tego, co współczesny językoznawca Artur Stęplewski ujął w następujący sposób: „[...] pismo jest pierwszą i wyraźną etykietą języka, odsyłającą nawet niespecjalistę do określonego kręgu kulturowego czy religijnego, [...] bywa [...] świadomym wyborem ideologicznym, który wiąże się z decyzjami politycznymi i społecznymi" ${ }^{31}$. Wydaje się, że tym samym pisarz znowu wyprzedził

30 J. Rompski, Wurvanô spjéva, dz. cyt., k. 125-126.

31 A. Stęplewski, Świadomość narodowa Słowian a kwestie językowe, w: Z mała ojczyzna $w$ sercu. Księga pamiątkowa dedykowana Profesorowi Tadeuszowi Zdancewiczowi, red. M. Walczak-Mikołajczakowa, B. Zieliński, Poznań 2005, s. 351. 
swój czas, o czym mogą świadczyć np. toczące się pod koniec XX i na początku XXI wieku spory o cyrylicę i łacinkę w dyskursie narodowym Serbów i Chorwatów ${ }^{32}$.

Dodajmy, że identyfikacja języka kaszubskiego jako odrębnego od polszczyzny języka słowiańskiego, której dokonał Florian Ceynowa, zaprowadziła go w kierunku kształtowania własnej grafii, która miała jak najwierniej oddawać cechy systemowe kaszubszczyzny ${ }^{33}$. Koncepcja Ceynowy położyła rzeczywiste podwaliny pod grafię języka kaszubskiego. Mimo wpływów idei panslawizmu na poglądy jej twórcy grafia języka kaszubskiego nie szła drogą tzw. słowiańsko-czeską, czyli nie zaadaptowała np. odwróconego cyrkumfleksu (haczek) do oznaczenia pewnych szyków spółgłosek, jak uczyniły to np. języki łużyckie czy język białoruski, lecz ciążyła w swoją stronę, przyjmując rozwiązania uznane przez autora za najodpowiedniejsze dla kaszubszczyzny ${ }^{34}$.

Po prawie 40 latach od ukazania się pierwszych kaszubskich tekstów kaszubocentrycznego Ceynowy zaczął się wykształcać nurt polonocentryczny, którego przedstawicielem był Hieronim Derdowski. Uznał on kaszubszczyznę za dialekt języka polskiego, a własne teksty zapisywał alfabetem polskim i wedle wszelkich prawideł polskiej grafii. W sumie, od połowy XIX wieku, pojawiło się co najmniej kilkanaście propozycji kaszubskiej grafii, w pewnym sensie zawsze odzwierciedlającej nastroje w grupie, która ją wykształciła, jako produkt końcowy wiedzy o języku, rozpoznania własnej tożsamości oraz względów użytkowych, praktycznych. Tak było np. w dwudziestoleciu międzywojennym, kiedy z jednej strony mieliśmy środowisko Zrzeszińców, rozwijających idee Ceynowy, a także jego propozycję grafii, a z drugiej np. środowisko skupione wokół wejherowskiego pisma „Klëka”, adaptujące niektóre rozwiązania grafii Zrzeszińców, ale niedążące w ogóle do

32 A. Stęplewski, Semioza pisma. Cyrylica i łacinka $w$ serbskim i chorwackim dyskursie narodowym na tle słowiańskim, dz. cyt.

33 M. Bandur, Pismo jako znak wspólnoty etnicznej. Głos w sprawie polityki języka kaszubskiego, w: Mniejszości etniczne i ich pogranicza. Szkice tożsamościowe, red. A. Kożyczkowska, M. Szczepska-Pustkowska, Gdańsk 2020, s. 327.

34 Tamże. 
budowania jakiejkolwiek normy językowej, co było wynikiem ich przekonania, że kaszubszczyzna jest dialektem języka polskiego ${ }^{35}$.

W 1974 roku swoje zasady grafii dla kaszubszczyzny zaproponowali Edward Breza i Jerzy Treder z Uniwersytetu Gdańskiego i już we wstępie do nich napisali, że pisownia kaszubska: „powinna być jak najbardziej zbliżona do pisowni języka polskiego literackiego; wówczas będzie jak najbardziej przystępna dla Kaszubów i innych Polaków oraz cudzoziemców"36. Niejako w odpowiedzi na to, w 1989 roku, powstała propozycja grafii „Tatczëznë”, grupy studenckich aktywistów skupionych wokół tworzonego przez siebie czasopisma, inspirowanych przez ks. Franciszka Gruczę, ostatniego żyjącego jeszcze Zrzeszyńca. W ich imieniu Eugeniusz Pryczkowski pisał: „trzeba jak najszybciej powrócić do pisowni historycznej (wypracowanej na przestrzeni prawie całego wieku od Floriana Ceynowy do Aleksandra Labudy) i do projektu Stefana Bieszka z 1959 r., osadzonego na gruncie języka, powtarzam - języka kaszubskiego"37.

Dyskurs kaszubocentryczny i polonocentryczny na przestrzeni prawie 180 lat, które minęły od opublikowania pierwszych kaszubskojęzycznych tekstów Floriana Ceynowy, prezentowały swoje odmienne wizje grafii kaszubskiej. Z jednej strony propozycję nieoglądającą się na wzorce polskie i oddającą cechy systemowe języka kaszubskiego, z drugiej zaś zmodyfikowaną grafię polską, oddającą pewne cechy kaszubskie, ale bezsprzecznie wyrastającą z polskiej normy, co z punktu widzenia np. językoznawstwa porównawczego i historycznego nadal może sytuować kaszubszczyznę po stronie dialektu lub derywatu / pochodnej polskiej odmiany ogólnej.

Zagadnieniu języka Jan Rompski poświęcił opublikowany w „Zrzeszë Kaszëbskji” artykuł zatytułowany Wo najim jęzeku. Redaktorzy gazety nie kryli, że zależy im na stworzeniu projektu języka literackiego, w którym odrzucaliby polonizmy i germanizmy, chętnie sięgając

35 Por. H. Makurat Cechy języka utworów poetyckich klëkowców, w: Poezja twórców kręgu „Klëki”, oprac. H. Makurat, Gdańsk 2015.

36 E. Edward, J. Treder, Zasady pisowni kaszubskiej, Gdańsk 1974, s. 5.

37 E. Pryczkowski, Fundament naszej tożsamości, „Lecëdło. Biuletyn II Kongresu Kaszubskiego", 1992 nr 2, s. 3. 
do słów zapomnianych, nadając im nowe znaczenia, tworząc neologizmy lub czerpiąc słownictwo $\mathrm{z}$ innych języków słowiańskich. Rompski w gronie tym należał do tych, którzy uważali, że przede wszystkim należy przyjąć zasadę, że język ,jidze z chëczë” [wychodzi z domu] ${ }^{38}$. Postulował, by posługiwać się słownictwem, składnią itd., itp., zapamiętanymi z przekazu rodzinnego i tenże przekaz wzbogacać ewentualnymi nowymi ogólnymi formami językowymi. O swoim przekonaniu o potrzebie odtworzenia międzypokoleniowej wspólnoty językowej pisał, zwracając uwagę, że szczególną wartość mają archaizmy, „bo v njech je najô prôvda" [bo w nich jest nasza prawda] ${ }^{39}$. Pisarz zauważał też zgubny wpływ języka polskiego, który już wtedy - pod koniec lat 30. XX wieku - był dominujący na Kaszubach, i przestrzegał, by nie naśladować w piśmie „dziseszniho ledztwa mjastovicho” [ludzi z dzisiejszych miast $]^{40}$, ponieważ skończyłoby się to pisaniem po polsku. Taką możliwość, jak już wiemy, odrzucał, co wyraził osobiście w słowach: „Żebejem mjoł koszlavjic se samiho dlo smjesznote dregjiho, a mojiho znjiżenjô, mojiho «jô» statecznô wupartosc mje nje dozwolô!" [Żebym miał koślawić siebie samego dla uciechy innych, a mojego poniżenia, ugruntowany upór mojego «ja» mi nie pozwala! $]^{41}$.

\section{Kultura w projekcie Rompskiego}

Intelektualna przyjaźń połączy Mirchova/Rãbiôka na jakiś czas z Zofią Zelevską. Zwrócił on na nią uwagę, kiedy na jej biurku w urzędzie zobaczył kaszubską powieść Aleksandra Majkowskiego. Spotykają się, by rozmawiać o przesłaniu Żëcô i przigód Remùsa. W rzeczywistości chodzi o coś więcej - o kaszubską kulturę. Nie tę świetlicową, ale opartą na mitach narodowych. Jan Rompski nawiązuje do nich już na samym początku Wurvani spjéve. Powieść otwiera bowiem dialog Chmiela i Mirchova, którzy w wiosenne popołudnie spacerują po pięknych lasach w okolicach Kartuz, są młodzi i spragnieni życia. Obaj są dziećmi tej

\footnotetext{
38 J. Rompski, Wo najim jęzeku, „Zrzesz Kaszëbskô”, 1938 rok 6 nr 6, s. 1-2.

39 Tamże.

40 Tamże.

41 Tamże.
} 
ziemi, krainy prostoty, która potrzebuje ich umysłów i sił twórczych, by przeobrazić się w krainę szczęśliwości. Za chwilę Mirchov swymi mocnymi rękami pochwyci symboliczne narzędzia: „pług i bronę” (Wurvanô spjéva, sygn. 3, s. 2) i wyruszy niczym apostoł posłany do Kaszubów, by głosić prawdę o nowym życiu. Obaj bohaterowie Rompskiego mają świadomość, że ich czas nadszedł. Do działania budzi „pomjon uszłech wjeków" [echo minionych wieków] (Wurvanô spjéva, sygn. 3, s. 1), czyli świadomość dziejów własnego ludu, znajomość jego historii i nadzieja na kulturowe odrodzenie. Chmiel żegna przyjaciela i żal mu, że odchodzi, opuszcza bliskie sercu okolice i zostawia dziewczynę, którą przecież kocha. Mirchov wyrzuca mu, że mówi do niego w taki sposób, jakby to była jego „pusta noc”, co w tradycji kaszubskiej oznacza rytuał ostatniego pożegnania osoby zmarłej, a on przecież zamierza wypełnić swoją misję i powrócić w rodzinne strony. Wyrusza, ponieważ jest to winien ojcu, który dał mu możliwość kształcenia się. Jego powinnością jest wspomóc rodzinę owocami swojej pracy. Bohaterowie Rompskiego przyrzekają sobie wzajemnie, że zawsze stanowić będą jedność. Pisarz posyła ich, by rozpalali kaszubskiego narodowego ducha na ołtarzu słowiańszczyzny. Wskazuje, że obaj są jak "Ciril i Metodi” (Wurvanô spjéva, sygn. 3, s. 1), swą misję poprowadzą nawet wbrew własnemu narodowi, który nie rozumie ich roli w historii, bez którego jednak nie ma dla nich nic poza śmiercią.

$\mathrm{Na}$ koniec sceny otwierającej powieść Rompski wplata w narrację pieśń o długiej, krętej i żmudnej drodze do wyśnionego „królestwa wubetku" [królestwa pokoju]. Recytuje ją Mirchov (Wurvanô spjéva, sygn. 3, s. 4), a czytelnik otrzymuje przesłanie, że owo królestwo osiągną jedynie ci, którzy nie będą biernie czekali, lecz podejmą trud pokonania drogi. To będą nowi ludzie, wyzbyci lęków i strachu. Gdy pieśń się kończy, bohaterowie Wurvani spjévë - Chmiel i Mirchov - pogrążeni w zadumie spoglądają w górę, a w miejscu chmur na niebie widzą ośnieżone szczyty gór i oblewające je bezkresne morze, które natychmiast zaczyna robić się niespokojne i groźne jak podczas burzy. Nagle jednak wszystko cichnie i zza chmur wychodzi złote słońce, które jawi się im niczym „czarownik” o wielkiej sile (Wurvanô spjéva, sygn. 3, s. 4a) i opromienia swym blaskiem Ziemię, rzekę Łebę i lasy mirachowskie. Zatrzymuje się na chwilę, po czym zachodzi za linię horyzontu. 
Dla kogoś, kto zna geografię Kaszub, staje się jasne, że jesteśmy w samym centrum krainy, gdzie od czasów średniowiecza życie ludzi skupia się wokół dwóch znaczących grodów: Chmielna i Mirachowa.

Dla uważnego czytelnika literatury kaszubskiej już tylko ta sytuacja z początku powieści Wurvanô spjéva może być sygnałem do zinterpretowania tego utworu jako elementu dialogu międzypokoleniowego odbywającego się pomiędzy Młodokaszubami, których liderami byli m.in. literaci Aleksander Majkowski, Jan Karnowski czy Leon Heyke, a Zrzeszyńcami - z Janem Trepczykiem, Aleksandrem Labudą i Janem Rompskim na czele. O związkach ideowych Rompskiego z pokoleniem skupionym wokół pisma „Gryf” pisali już Jan Drzeżdżon i Daniel Kalinowski ${ }^{42}$. Przywoływane przez autora Wurvani spjévë żywioły i siły natury, wyrażające się w słońcu, chmurach, wietrze, wodach i lasach, świadczą nie tylko o pogańskim kulcie solarnym, ale i o słowiańskim kulcie wody i drzew, które to motywy pierwsi zaszczepili kaszubskiej literaturze Młodokaszubi ${ }^{43}$. Ale nie są to jedyne znaki, które stały się rozpoznawalne w literaturze kaszubskiej przede wszystkim dzięki Majkowskiemu - jego powieści Żëcé i przigòdë Remùsa oraz pracy zatytułowanej Historia Kaszubów ${ }^{44}$. Odnajdziemy w utworze Rompskiego np. mit Wielkiego Pomorza, którego Kaszubi, jako niedobitki „sławnego na lądzie i morzu narodu Pomorzan"45, są strażnikami i które stanowi ich ojczyznę ideologiczną. Oczami Mirchova ujrzymy postać księcia Świętopełka Wielkiego (Wurvanô spjéva, sygn. 3, s. 190-191), średniowiecznego władcy Pomorza Gdańskiego, twórcy jego potęgi i obrońcy niezawisłości ${ }^{46}$. Stanie przed nami król Przemysł z wielkopolskiej linii Piastów, ten sam, który w 1282 roku zawarł układ w Kępnie z Mści-

42 Por. J. Drzeżdżon, Piętno Smętka. Z problemów kaszubskiej literatury regionalnej lat 1920-1939, Gdańsk 1973; D. Kalinowski, Pieśń i sława. O liryce Zrzeszyńców, w: Poezja Zrzeszyńców, red. J. Borzyszkowski, D. Kalinowski, H. Makurat, Gdańsk 2013.

43 T. Linkner, Heroiczna biografia Remusa. W zwierciadle mitu i kaszubskich wierzeń, Gdańsk 1996, s. 185.

44 Por. tamże, s. 40-49.

45 A. Majkowski, Historia Kaszubów, Gdańsk 1991, s. 12.

46 Por. M. ̌̌eznik, Średniowieczna ikona nowoczesnej tożsamości? „Testament Mestwina" w kaszubskich reprezentacjach literackich od Aleksandra Majkowskiego 
wojem, następcą Świętopełka, na mocy którego objął ziemię kaszubską we władanie po śmierci swego pomorskiego wuja. Przemkną nam przed oczami zastępy wojsk krzyżackich, które wkraczając w listopadową noc 1308 roku do Gdańska, odebrały Kaszubom niezawisłość, zgodnie z tym, jak interpretowali historię Zrzeszyńcy. W naszą duszę zajrzy Smętk, którego Rompski, podobnie jak Majkowski, utożsamia przede wszystkim z zewnętrznymi mocami zła zagrażającymi losowi Kaszubów ${ }^{47}$, oraz jego towarzyszki „sowë” [sowy], które w powieści Majkowskiego swymi skrzydłami gaszą iskry mające rozpalać do czynu Kaszubów. Wreszcie stanie przed nami i sam Remus, rycerz kaszubski „bez wiarë, chtërna zgrużdżony, wumarło koło jego nóg sedzi" [pozbawiony wiary, która skulona, martwa koło nóg jego siedzi] (Wurvanô spjéva, sygn. 3, s. 191).

Znaki i symbole kultury narodowej są także istotną częścią obrazu, który maluje Mirchov w swojej pracowni w Wejherowie. Widoczne na nim wojsko „spod znaku słońca” po raz kolejny przywołuje na myśl ideę dziedziczenia przez Kaszubów spadku plemion słowiańskich, żyjących niegdyś na całym Pomorzu, dla których naczelnym bóstwem był Swaróg-Swarożyc, bóg jasności i słońca. Miejscem jego kultu była Retra-Reda, a w niej święty gaj zwany Redgoszcz ${ }^{48}$. Zamek może być symbolem kaszubskiej państwowości, którą dawno już pokryły mroki dziejów. Sprzysiężone siły zła, jakie zawisły nad morzem, ziemią oraz przykryły także niebo i zwyciężają w tej bitwie, to alegoria faszystowskich Niemiec. Malowidło Mirchova jest zatem nawiązaniem do odwiecznego konfliktu germańsko-słowiańskiego, który akcentował w swojej twórczości już Florian Ceynowa, poczynając od Die germanisierung der Kaschuben. Von einem Kaschube, a po nim kolejni kontynuatorzy myśli kaszubskiej, o czym obszerniej pisał już Daniel Kalinow-

po Lecha Bądkowskiego, w: Wielkie Pomorze. Społeczności i narody, red. D. Kalinowski, A. Kuik-Kalinowska, Gdańsk-Słupsk 2017, s. 61-62.

47 T. Linkner, Heroiczna biografia Remusa. W zwierciadle mitu i kaszubskich wierzeń, dz. cyt., s. 131-132.

48 Por. G. Labuda, Mitologia i demonologia $w$ słownictwie, w bajkach, baśniach i legendach kaszubskich, w: Świat bajek, baśni i legend kaszubskich. Materiały z sesji naukowej, red. T. Bolduan, Wejherowo 1979, s. 13. 
$\mathrm{ski}^{49}$. Konfrontację tę tym razem wygrają Niemcy. Po ich wkroczeniu do Wejherowa i odkryciu ruin „szklanej izby” Mirchova płótno zostaje najpierw rozdarte kolbą niemieckiego karabinu, a następnie spalone przez żołnierza w mundurze Wehrmachtu z „szatańskim uśmiechem” na twarzy. Nadzieja pozostanie w dziecku, które wyniósł z potępieńczej pożogi gryf - pół ptak, pół lew, uosabiający męstwo i odwagę, od XII stulecia utożsamiany z Gryfitami, władcami Księstwa Pomorskiego, a od początku XX stulecia za sprawą Aleksandra Majkowskiego także symbol ruchu kaszubskiego.

\section{Polityka w projekcie Rompskiego}

W kolejnych częściach powieści Jan Rompski rozwija także motyw obywatelskości Kaszubów, ich reprezentacji w życiu polityczno-społecznym Polski. Łączy ten temat w oczywisty sposób z przemyśleniami o języku, narodzie i roli kaszubskiej inteligencji. Stara się ponadto umiejscowić Kaszuby w międzynarodowej polityce. Rozważa polityczne kroki nazistowskich Niemiec czy geopolityczne położenie Polski, której przecież zagraża również Rosja od wschodu. Interesuje się Gdańskiem, w którym rozkwitł niemiecki narodowy socjalizm. Myśli o miejscu Kaszub w świecie po nieuchronnej wojnie, do której zmierza ludzkość. Rozbudowuje oniryczne wizje lepszego świata, a także tworzy nowe, katastroficzne scenariusze wynikające z przeświadczenia Mirchova o nieuniknionej zagładzie obecnej formy cywilizacji, co niechybnie nastąpi. Nie uniknie katastrofy również wszystko to, co składa się na pojęcie kultury Kaszubów.

Dylemat, jakie jest miejsce Kaszubów w Polsce i na świecie, pojawia się także podczas spotkań w Toruniu. Tam, w mieszkaniu Aleksa Łabędzkjego, będącego w gruncie rzeczy alter ego Aleksandra Labudy, jednego z liderów Zrzeszyńców, który od 1938 roku do wybuchu wojny rzeczywiście mieszkał i pracował w stolicy Pomorza, spotykają się kaszubscy inteligenci pragnący przygotować coś w rodzaju wspomnia-

49 D. Kalinowski, Pieśń i sława. O liryce Zrzeszyńców, w: Poezja Zrzeszyńców, dz. cyt., s. 195. 
nego już Zjazdu / Kongresu Kaszubskiego. Zebrani: Jan Rębjok, Aleks Łabędzkji, Franc i Wojk, są przekonani, że jedynie pozytywistyczna praca, do której potrzeba „pługa i brony”, narzędzi służących do codziennej, żmudnej orki, może przynieść efekt w postaci odrodzenia kaszubskiej kultury. Myśl o pracy u podstaw najprawdopodobniej przyświecała autorowi Wurvani spjévë w chwili, kiedy swojemu utworowi nadawał podtytuł Powiesc z czasów kaszëbskjego pozitivjizmu (Wurvanô spjéva, sygn. 3, s. tytułowa).

Mirchov i jego towarzysze odnoszą sukcesy w pracy, która ma służyć temu, „bë ti zemi dac nazôd ji człowieka” [by tej ziemi przywrócić jej człowieka] (Wurvanô spjéva, sygn. 3). Widzą, że „kwiatuje krutka kaszëbsczégò żëcô" [kwieci się bukiet kaszubskiego życia] (Wurvanô spjéva, sygn. 3). Jednocześnie jednak muszą mieć wolę mocną jak „stolem” [olbrzym] i twardą ,jak klif”, jeśli chcą „zdrov zorno zapravic na role" [zasiać zdrowe ziarno na roli] (Wurvanô spjéva, sygn. 3). Ale niełatwo jest być prorokiem wśród swoich, szczególnie jeśli ci nie chcą zmian lub ich nie rozumieją. Najczęstsze reakcje tzw. prostego ludu wyraża w powieści Rompskiego gospodyni i ciotka głównego bohatera Barzónka - dopuszczona przez autora do głosu jako jedyna w zasadzie przedstawicielka warstwy nieinteligenckiej. „Co wa sobie ùdba jesta mówi do Mirchova - może was wieczną biédã kòsztowac - czë témù Kaszëbie nie je równo, chto mù bótë robi, bële miôl w czim chòdzëc?" [To, co sobie wymyśliliście, może was kosztować wieczną biedę - czy przeciętnemu Kaszubie nie jest obojętne, kto mu buty robi, byle miał w czym chodzić?] (Wurvanô spjéva, sygn. 3, s. 45). Część rodzimej inteligencji ma przekonania podobne do myślenia Barzónki.

Ważki temat, który autor powieści podejmuje w rozważaniach Mirchova, to również sytuacja polityczno-militarna w Europie. Plany związane z organizacją zjazdu inteligencji kaszubskiej zostają pokrzyżowane. Wobec nieludzkiego hitleryzmu, niewiary w możliwości państw Europy Zachodniej, niewiadomej reakcji Rosji Radzieckiej sprawa kaszubska będzie musiała pozostać powiązana z losami Polski. Mirchov najlepiej wie, że przez 19 lat rządów nad Pomorzem Polska nie raz pokazała, że nie szanuje Kaszubów, którzy oddali jej przecież morze, tak pilnie strzeżone przez wieki trwania na południowym brzegu Bałtyku. Mirchov wie, jak traktowano Kaszubów w budującej się i rozwijającej na nadmorskim 
brzegu Gdyni, gdzie na przykład robotników pochodzących z Kaszub, w sytuacjach kryzysowych, zgodnie z obowiązującym prawem, zwalniano w pierwszej kolejności. Jednak w Wurvani spjévje mówi: „momë v wudzale przeżivac ji tragedie i też wjalgosc" [udziałem naszym jest przeżywać jej tragedie i wielkość] (Wurvanô spjéva, sygn. 3). Nadzieję na sukces projektu narodowego upodmiotowienia wszystkich Kaszubów pod przywództwem warstwy inteligenckiej Jan Rompski pogrzebie w powieści ostatecznie we wrześniu 1939 roku w wojskowych okopach na Kępie Oksywskiej. W wizji pisarza to tam zamilkły nagle dźwięki odwiecznej pieśni nuconej przez pokolenia Kaszubów. W obliczu wrześniowej klęski została „wurvanô spjéva” - urwały się pienia pokolenia Zrzeszyńców.

Mirchov pod wpływem najazdu hitlerowskich Niemiec na Polskę i Kaszuby traci wiarę w porządek świata i próbuje odnaleźć sens w spodziewanej gwałtownej zagładzie. W rozmowie z sekretarzem miasta Jagódką mówi:

Głëpstvę je vjerzec w jakąs dobrą wolę svjata. Każdi kwuje na swoj ôrt żelazło, vjedno nôprzod dlô se. Rzeczę cë, leno më, Kaszëbji nji mjele jesmë svégwo kovala! Tému téż jesmë jakno żużel i za taczi téż nas trzimają. Czejbë nji wokropnosc vojnë, rzekłbëm: njech przińdze, njech moja krev choc vëpije. To cë jednak rzeknã, że ta vojna mdze bjôtką wo novi wid, wo dobro lëdzkoscë. Më lëdze jesmë statkę do tego, zevnętrzną formą. Słabi zlegną mocnjészim. [...] Niejeden słëga dobra mdze musził jic ze słëgą zła $\mathrm{v}$ te bjotczi [...] Z krzëkvë ti vëdobądze sę jeden gromjisti głos, co mdze za spraviedlëwoscą, dobrę! ${ }^{50}$.

[Głupotą jest wierzyć w jakąś dobrą wolę świata. Każdy kuje żelazo na własny sposób, ale zawsze najpierw dla siebie. Powiem ci, tylko my, Kaszubi nie mieliśmy swojego kowala. Dlatego też jesteśmy niczym żużel i za taki też nas inni mają. Gdyby nie okropności wojny, powiedziałbym: niech przyjdzie, niech choć i mą krew wypije. Ale powiem ci, że ta wojna będzie bitwą o nowe światło, o dobro człowieczeństwa. My, ludzie, jesteśmy naczyniem dla tego [światła - A.J.], zewnętrzną formą. Słabi ulegną mocniejszym. [...] Niejeden sługa dobra będzie musiał iść po jednej stronie ze

50 J. Rompski, Wurvanô spjéva, dz. cyt., k. 123. 
sługą zła w tych bojach. [...] Z pożogi tej wydobędzie się jeden doniosły głos, który będzie za sprawiedliwością, dobrem!]

Bohater powieści Jana Rompskiego uważa, że narodowy socjalizm nie jest drogą do modernizacji świata. Prosi też, żeby go nie brać za komunistę, ponieważ to byłoby nieporozumieniem. Podkreśla, że nie jest absolutnie wrogiem Polski, a gdy będzie trzeba, przeleje za nią krew:

Boli mje kożdo ji rena, bo móm ji żëłë, le krev płenje Pomorzôka, chterną dóm ji czej mdze potrzeb. Leno skomę móm za novą, spraviedlëvą, na vzajemni róvnoscë pravóc vszëtczich narodów, zbudacëję narodów słovjańsczich, złączoni wunią gospodarczą z jinyma narodama sviata. Niech kòżdi zgódno ze svòjim dëchę klëje kulturę svoją. Njech provadzi svoję politikę zrozmienjô woglovégò dobra. Bële kożdi czëł sę wolni, czëł spraviedlëwą wopjekã prava, czej mdze konieczné51.

[Boli mnie każda jej rana, bo mam jej żyły, tylko krew płynie Pomorzanina, oddam ją dla niej, jeśli zajdzie taka potrzeba. Pragnę jedynie nowej, sprawiedliwej, opartej na wzajemnych prawach wszystkich narodów, ze wspólnotą narodów słowiańskich, złączonej unią gospodarczą z pozostałymi narodami świata. Niechaj każdy w zgodzie z własnym duchem kuje swą kulturę. Niechaj prowadzi własną politykę zrozumienia dobra wspólnego. Byle każdy czuł się wolny, czuł sprawiedliwą opiekę prawa, kiedy zajdzie taka potrzeba.]

\section{Podsumowanie}

Zasadnicze założenia projektu, mającego pomóc w kreacji wyobrażenia narodu, którego przedstawicielami czuli się Zrzeszyńcy, można przedstawić w czterech punktach: 1) kaszubski to autonomiczny słowiański język; 2) Kaszubi są odrębnym etnicznie narodem; 3) Kaszubi są obywatelami państwa polskiego i w znaczeniu politycznym czują wspólnotę z narodem polskim; 4) siłą przewodnią Kaszubów jest rodzima in-

51 Tamże, k. 125. 
teligencja ${ }^{52}$. Zawartość semantyczna słowa naród (kasz. nôrod) - 'to, co się narodziło / zostało narodzone’ od czasownika narodzić się jest podobna we wszystkich językach słowiańskich. Jak zauważa Julia Legomska: „referentem nazwy naród [...] jest zbiór elementów połączonych jakimiś więzami. Rodzaj elementów, charakter więzi oraz ich konfiguracja wyznaczają różne ścieżki profilowania pojęcia naród"53. Nie inaczej widzieli to Zrzeszyńcy, przypisując inteligencji szczególną rolę w konstruowaniu wspólnoty.

Jan Rompski, jako aktywny uczestnik narodowościowego dyskursu i inteligent, w stworzonym przez siebie tekście podjął świadomą próbę kreacji rzeczywistości. Projekt narodowy jego i jego towarzyszy z ideowo-literackiej grupy Zrzeszyńców polegał na tym, żeby do utrwalonej wizji świata swoich czytelników wprowadzić zapoznane elementy - zbiór mitów - odtwarzanego kanonu kultury, do którego należy także przekonanie, że Kaszubi to resztki wielkiego niegdyś narodu „Weletów”. Rompski uczynił z tego ważną część narracji swojej jedynej powieści. Dał w niej również wyraz swojemu przeświadczeniu, że jednym z najważniejszych elementów narodowotwórczych jest język. Ważna jest jego standaryzacja, a autonomiczna ortografia stanowi wyraźną etykietę języka. Świadoma własnej odrębności narodowej inteligencja, angażująca się w życie wspólnoty obywatelskiej (państwowej), musi jednocześnie odegrać kluczową rolę $\mathrm{w}$ odrodzeniowym procesie tożsamościowym i podjąć pracę u podstaw z „ludem”, który bezrefleksyjnie dziedziczy kulturę pradawnych Pomorzan.

Pisarz, sam będąc przeświadczony o potrzebie narodowego upodmiotowienia się Kaszubów, przekonywał, że jest to jedyna droga do zachowania i rozwoju dziedzictwa słowiańskiego etnosu, który od wieków jest gospodarzem na południowym brzegu Bałtyku. Jako opowieść o wyobrażonym narodzie kaszubskim Wurvanô spjéva niesie również ważne przesłanie skierowane do polskiego odbiorcy. Jan Rompski zawarł

52 Por. D. Szymikowski, Zrzesz Kaszëbskô w latach 1933-1939, dz. cyt., s. 123-145; A. Kożyczkowska, Kaszubszczyzna. Pedagogicznie o języku i tożsamości, dz. cyt., s. 85-89.

53 J. Legomska, Państwo, naród, ojczyzna w dawnej polszczyźnie: leksykalno-semantyczny opis pojęć, Katowice 2010, s. 80-81. 
bowiem na kartach powieści nieustanne rozważania na temat tego, jak z jego perspektywy wyglądały, wyglądają i powinny wyglądać relacje polsko-kaszubskie oraz kaszubsko-polskie. Z licznych monologów głównego bohatera, a także prowadzonych przez niego dialogów z uczestnikami życia publicznego w wykreowanym, powieściowym świecie płynie orędzie pisarza, które charakteryzuje nadzieja na zrozumienie przez Polaków działań podejmowanych przez Kaszubów na rzecz swojej kultury i języka. Okazane zaufanie i pomoc Kaszubom w realizacji ich żywotnych dążeń jest kluczem - tak zdaje się przekonywać Jan Rompski - do wspólnoty obywatelskiej w państwie polskim. To przekonanie twórcy, ten apel o wzajemny szacunek powróci w posłaniu zawartym w jego późniejszej poezji i dramatach.

\section{Bibliografia}

[b.a.]. „Kaszubi, poznajmy swą przeszłość!”. Zrzesz Kaszëbskô rok 1 nr 24 (1933): 1-2.

[b.a.]. „Kilka słów o nazwach i herbie Kaszubów”. Zrzesz Kaszëbskô rok 1 nr 31 (1933): 1-2.

Bachtin, Michaił. „Nauka o ideach a filozofia języka”. W: Bachtin - dialog, język, literatura, red. Eugeniusz Czaplejewicz, Edward Kasperski, 74-80. Warszawa: Państwowe Wydawnictwo Naukowe, 1983.

Bandur, Maciej. „Pismo jako znak wspólnoty etnicznej. Głos w sprawie polityki języka kaszubskiego". W: Mniejszości etniczne i ich pogranicza. Szkice tożsamościowe, red. Adela Kożyczkowska, Maria Szczepska-Pustkowska, 326-337. Gdańsk: Wydawnictwo Uniwersytetu Gdańskiego, 2020.

Breza, Edward. Treder, Jerzy. Zasady pisowni kaszubskiej. Gdańsk: Wydawca Zarządu Głównego Zrzeszenia Kaszubsko-Pomorskiego, 1974.

Dijk, Teun van. „Kontekstualizacja w dyskursie parlamentarnym”. W: Krytyczna analiza dyskursu, red. Anna Duszak, Norman Fairclough, 215-244. Kraków: Towarzystwo Autorów i Wydawców Prac Naukowych „Universitas", 2008.

Drzeżdżon, Jan. Piętno Smętka. Z problemów kaszubskiej literatury regionalnej lat 1920-1939. Gdańsk: Wydawnictwo Morskie, 1973. 
Foucault, Michel. Nadzorować i karać. Narodziny więzienia, tłum. Tadeusz Komendant. Warszawa: Wydawnictwo Aletheia, Spacja, 1993.

Foucault, Michel. Porządek dyskursu. Wykład inauguracyjny wygłoszony w College de France 2 grudnia 1970, tłum. M. Kozłowski. Gdańsk: Wydawnictwo Słowo/obraz terytoria, 2002.

Hroch, Miroslav. Małe narody Europy, tłum. Grażyna Pańko. Wrocław: Zakład Narodowy im. Ossolińskich, 2003.

Jabłoński, Artur. Narracja Jana Rompskiego o narodzie kaszubskim. Rozprawa doktorska napisana pod kierunkiem prof. Jolanty Tambor. Katowice: Uniwersytet Śląski, 2019. Internet: https://fbc.pionier.net.pl/details/nnV4nwq (dostęp: 16.04.2020).

Kalinowski, Daniel. „Pieśń i sława. O liryce Zrzeszyńców”. W: Poezja Zrzeszyńców, oprac. i przypisy Hanna Makurat, wstęp Józef Borzyszkowski, Daniel Kalinowski, Hanna Makurat, LXXXIII-LXXXIV. Gdańsk: Instytut Kaszubski, 2013.

Kożyczkowska, Adela. Kaszubszczyzna. Pedagogicznie o języku i tożsamości. Gdańsk: Wydawnictwo Uniwersytetu Gdańskiego, 2019.

Kutta, Janusz. Druga Rzeczpospolita i Kaszubi. Bydgoszcz: Wydawnictwo Pozkal, 2003.

Labuda, Gerard. Mitologia i demonologia $w$ słownictwie, $w$ bajkach, baśniach i legendach kaszubskich. W: Świat bajek, baśni i legend kaszubskich. Materiały z sesji naukowej, red. Tadeusz Bolduan, 5-63. Wejherowo: Muzeum Piśmiennictwa i Muzyki Kaszubsko-Pomorskiej, 1979.

Legomska, Julia. Państwo, naród, ojczyzna w dawnej polszczyźnie: leksykalno-semantyczny opis pojęć. Katowice: Wydawnictwo Uniwersytetu Śląskiego, 2010.

Linkner, Tadeusz. Heroiczna biografia Remusa. W zwierciadle mitu i kaszubskich wierzeń. Gdańsk: Oficyna Czëc,1996.

Łepkowski, Tadeusz. „Historyczne kryteria polskości”. ZNAK nr 11-12(390-391) (1987): 5-14.

Majkowski, Aleksander. Historia Kaszubów. Gdańsk: Wydawca Zrzeszenie Kaszubsko-Pomorskie, 1991.

Makurat, Hanna. „Cechy języka utworów poetyckich klëkowców”. W: Poezja twórców kręgu „Klëki”, oprac. Hanna Makurat, wstęp Józef Borzyszkowski, Adela Kuik-Kalinowska, Hanna Makurat, LXIX-CXXXI. Gdańsk: Instytut Kaszubski, 2015. 
Pryczkowski, Eugeniusz. „Fundament naszej tożsamości”. Lecëdło. Biuletyn II Kongresu Kaszubskiego nr 2 (1992): 2-3.

Řeznik, Milos. „Średniowieczna ikona nowoczesnej tożsamości? «Testament Mestwina» w kaszubskich reprezentacjach literackich od Aleksandra Majkowskiego po Lecha Bądkowskiego". W: Wielkie Pomorze. Społeczności i narody, red. Daniel Kalinowski, Adela Kuik-Kalinowska, 55-92. Gdańsk-Słupsk: Instytut Kaszubski, Akademia Pomorska w Słupsku, 2017.

Rompski, Jan. „Wo najim jęzeku”. Zrzesz Kaszëbskô rok 6 nr 6 (1938): 1-2.

Rompski, Jan. Wurvanô spjéva. W: Spuścizna Jana Rompskiego, sygn. 3. Wejherowo: Muzeum Piśmiennictwa i Muzyki Kaszubsko-Pomorskiej.

Sejm Rzeczypospolitej o Pomorzu w 1920 roku. Sprawozdanie Komisji Pomorskiej, oprac. Józef Borzyszkowski, Przemysław Hauser. Gdańsk: Zrzeszenie Kaszubsko-Pomorskie, 1985.

Spuścizna Jana Rompskiego, sygn. 3. Wejherowo: Muzeum Piśmiennictwa i Muzyki Kaszubsko-Pomorskiej.

Stęplewski, Artur. „CZzy Atatürk był gejem?». Konstruowanie Obcego w tureckich i greckich mediach". Dziennikarstwo i Media nr 14 (2020): 47-58. DOI: https://doi.org/10.19195/2082-8322.14.4.

Stęplewski, Artur. Semioza pisma. Cyrylica i łacinka w serbskim i chorwackim dyskursie narodowym na tle stowiańskim. Poznań: Wydawnictwo Naukowe Uniwersytetu Adama Mickiewicza, 2018.

Stęplewski, Artur. „Świadomość narodowa Słowian a kwestie językowe”. W: Z mała ojczyzna $w$ sercu. Ksiega pamiatkowa dedykowana Profesorowi Tadeuszowi Zdancewiczowi, red. Mariola Walczak-Mikołajczakowa, Bogusław Zieliński, 351-359. Poznań: Wydawnictwo Naukowe UAM, 2005.

Szymikowski, Dariusz. Z dziejów stosunków kaszubsko-czeskich. Korespondencja Aleksandra Majkowskiego z Antoninem Frintą 1912-1935. Gdynia: Wydawnictwo Region, 2006.

Szymikowski, Dariusz. Zrzesz Kaszëbskô w latach 1933-1939. Bolszewo: Biblioteka Gminy Wejherowo, 2010. 